\title{
Lack of Glucagon Response in Glucose Counter-Regulation in Type 1 (Insulin-Dependent) Diabetics: Absence of Recovery After Prolonged Optimal Insulin Therapy
}

\author{
G. Bolli ${ }^{1}$, G. Calabrese ${ }^{1}$, P. De Feo ${ }^{1}$, P. Compagnucci ${ }^{2}$, G. Zega ${ }^{1}$, G. Angeletti ${ }^{1}$, \\ M.G. Cartechini ${ }^{2}$, F. Santeusanio ${ }^{2}$ and P. Brunetti ${ }^{1}$ \\ Institutes of ${ }^{1}$ Medical Pathology and ${ }^{2}$ Clinical Medicine, University of Perugia, Italy
}

\begin{abstract}
Summary. Mild hypoglycaemia was induced using an artificial pancreas in five normal subjects (from 5.00 \pm 0.15 to $2.83 \pm 0.15 \mathrm{mmol} / 1$ ) by infusing $28 \mathrm{mU} / \mathrm{m}^{2}$ per min soluble insulin for $60 \mathrm{~min}$. Six Type 1 (insulin-dependent) diabetic patients were stabilized for $14 \mathrm{~h}$ using an artificial pancreas. They were then rendered hypoglycaemic (from $4.94 \pm 0.09$ to $2.89 \pm$ $0.11 \mathrm{mmol} / \mathrm{l}$ ) by infusing $28 \mathrm{mU} / \mathrm{m}^{2}$ per min plus 16 $\pm 3.8 \mathrm{mU} / \mathrm{min}$ insulin for $60 \mathrm{~min}$. Before the study, the diabetic patients were in optimal blood glucose control (mean blood glucose $6.72 \pm 0.11 \mathrm{mmol} / 1$ over the previous $14-20$ days; $\mathrm{HbA}_{1} 8.3 \pm 0.1 \%$ ). During the insulin infusion test, blood glucose decrement was slower in the diabetic patients than in the control subjects. The blood glucose nadir was delayed in the diabetics until 75 min compared with 55 min in the control subjects. Blood glucose recovery rate in the diabetic subjects was severely impaired. In Type 1 diabetes, the counter-regulatory hormonal response to insulin induced hypoglycaemia is similar to that of non-diabetics, except for that of glucagon, the blunted response of which is not reversed by prolonged optimisation of blood glucose control. This impaired response of the A cell does not seem to be a consequence of insulin deficiency.
\end{abstract}

Key words: Catecholamines, cortisol, glucagon, glucose counter-regulation, growth hormone, hypoglycaemia.

A number of studies have clearly established the primary role of glucagon [1] and catecholamines [2, 3] and the non-essential role of cortisol and growth hormone $[3,4]$ in counteracting insulin-induced hypoglycaemia in normal subjects. Studies investigating the counter-regulatory hormonal response to insulin- induced hypoglycaemia in diabetics are less numerous in the literature and contrasting results have been reported. Glucagon response to hypoglycaemia has generally been found blunted or suppressed in diabetics [5-12]. The response of catecholamines [12], cortisol and growth hormone $[5,8,12]$ in diabetics has generally been reported to be similar to that of normal subjects. However, Saccà et al. [9] have described a blunted response of noradrenaline to hypoglycaemia in diabetics, and Campbell et al. [10] a suppressed response of cortisol and growth hormone in $50 \%$ of their diabetic patients.

Previous studies have generally investigated diabetics with long-term hyperglycaemia. In these subjects the chronically high blood glucose levels could alter the counter-regulatory mechanisms. A study of insulin-induced hypoglycaemia arising in diabetics with long-term near-normal blood glucose levels might clarify on the real mechanisms of the hormonal counter-regulatory response.

We have investigated the pattern of hormonal counter-regulatory response to a moderate, insulininduced blood glucose fall in diabetics examined in conditions as similar as possible to those of non-diabetics, i.e. in normoglycaemia. In particular, we have attempted to determine whether the well known blunted response of glucagon to hypoglycaemia in diabetics could be normalised by a previous period of prolonged normoglycaemia.

\section{Subjects and Protocols}

Informed written consent was obtained from five normal volunteers and six diabetic subjects.

The normal subjects were aged between 24-32years (27 \pm 1.4 years) and were within $10 \%$ of ideal body weight [Metropolitan Life Insurance Tables, 1959]. None had a family history of diabetes or an abnormal glucose tolerance test. No subject was taking medi- 
Table 1. Clinical features of diabetic patients

\begin{tabular}{|c|c|c|c|c|c|c|c|c|c|c|c|c|c|c|c|}
\hline \multirow{3}{*}{ 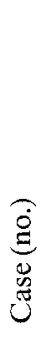 } & \multirow[b]{3}{*}{ 希 } & \multirow{3}{*}{ 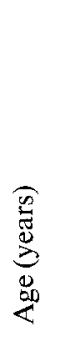 } & \multirow{3}{*}{ 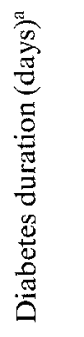 } & \multirow{3}{*}{ 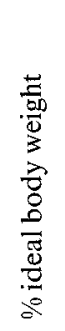 } & \multirow{3}{*}{ 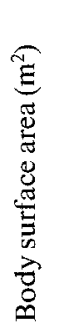 } & \multirow{2}{*}{\multicolumn{2}{|c|}{$\begin{array}{l}\text { Immuno-reac- } \\
\text { tive C-peptide } \\
(\mathrm{ng} / \mathrm{ml})\end{array}$}} & \multirow{2}{*}{\multicolumn{2}{|c|}{$\begin{array}{l}\text { Mean daily plasma } \\
\text { glucose (mmol/1) }\end{array}$}} & \multicolumn{4}{|c|}{ Total daily insulin dose (units) } & \multirow{2}{*}{\multicolumn{2}{|c|}{$\begin{array}{l}\text { Circulating } \\
\text { ketoamine- } \mathrm{HbA}_{\mathrm{I}}[22] \\
(\%)\end{array}$}} \\
\hline & & & & & & & & & & \multicolumn{2}{|l|}{ a } & \multicolumn{2}{|l|}{ b } & & \\
\hline & & & & & & basal & $90 \min ^{\mathrm{b}}$ & $\mathrm{a}$ & & $\begin{array}{l}\text { Solu- } \\
\text { ble }\end{array}$ & $\begin{array}{l}\text { Lente } \\
\text { insulin }\end{array}$ & $\begin{array}{l}\text { Solu- } \\
\text { ble }\end{array}$ & $\begin{array}{l}\text { Lente } \\
\text { insulin }\end{array}$ & a & $\mathrm{b}$ \\
\hline 1 & $\mathrm{M}$ & 39 & 1800 & 95 & 1.77 & 0 & 0.40 & $7.39 \pm 0.72$ & $6.44 \pm 0.39$ & 4 & 20 & 10 & 24 & 8.7 & 7.8 \\
\hline 2 & $\mathrm{~F}$ & 36 & 2730 & 92 & 1.60 & 0 & 0.40 & $6.94 \pm 0.61$ & $6.56 \pm 0.44$ & 10 & 22 & 16 & 30 & 9.1 & 8.5 \\
\hline 3 & $\mathrm{M}$ & 29 & 30 & 88 & 1.52 & 0 & 0.15 & $8.67 \pm 0.39$ & $6.00 \pm 0.44$ & 0 & 10 & 6 & 16 & 9.4 & 8.5 \\
\hline 4 & $\mathrm{M}$ & 18 & 15 & 97 & 1.84 & 0 & 0.15 & $6.11 \pm 0.72$ & $6.17 \pm 0.50$ & 14 & 30 & 16 & 30 & 8.4 & 8.4 \\
\hline 5 & $\mathrm{M}$ & 23 & 4201 & 108 & 1.51 & 0 & 0.25 & $7.56 \pm 0.50$ & $6.56 \pm 0.33$ & 12 & 32 & 14 & 32 & 8.5 & 7.8 \\
\hline 6 & $\mathrm{M}$ & 24 & 30 & 96 & 1.68 & 0 & 0.25 & $8.06 \pm 0.50$ & $6.28 \pm 0.39$ & 8 & 20 & 14 & 28 & 9.6 & 8.2 \\
\hline
\end{tabular}

$a=$ on admission; $b=$ immediately before the insulin infusion test (14-20 days after admission)

${ }^{a}$ On admission

b After a mixed meal

cations at the time of the study nor showed intercurrent illness. A diet with at least $250 \mathrm{~g}$ carbohydrate/day was recommended during the week before the study. After overnight fasting, the normal subjects were connected through a double-lumen catheter to an artificial endocrine pancreas (Biostator, Miles Laboratories, Elkahrt, Indiana, USA) for continuous blood glucose monitoring. Between 10.30 and $11.00 \mathrm{~h}$ an infusion of soluble insulin (Actrapid, Novo Industri, Copenhagen, Denmark) was started and continued at a constant rate $\left(28 \mathrm{mU} / \mathrm{m}^{2}\right.$ body surface area $\left./ \mathrm{min}\right)$ for $60 \mathrm{~min}$ by Biostator. Blood glucose monitoring was continued up to $120 \mathrm{~min}$. One litre $0.9 \%$ saline was infused over $2 \frac{1}{2} \mathrm{~h}$ (from -30 to $120 \mathrm{~min}$ ) via an indwelling catheter placed in an antecubital vein of the free arm. This access was used for blood sampling for hormone analysis.

The diabetic group consisted of six Type 1 (insulin-dependent) diabetics, the clinical features of whom are summarized in Table 1. No patient had symptoms of peripheral or autonomic neuropathy and in all patients the deep-breathing test [13], motor and sensory nerve conduction velocity and fundoscopic examination were normal (except for case 1, who showed a slight reduction of sensory nerve conduction velocity). No patient was taking medication other than insulin at the time of the study nor showed intercurrent illness. Diabetics admitted to the protocol were selected from patients attending our metabolic unit because they showed good blood glucose control over the period of observation (14-20 days) while on daily multiple insulin injections. Table 2 summarizes the indices of blood glucose control determined over 14-20 days (mean $18 \pm 1$ days) before the test. During this period venous blood was drawn daily for measurement of plasma glucose whilst fasting, and $22 \pm 1.7$ times $90 \mathrm{~min}$ after meals. Glycaemic profiles (plasma glucose on fasting, $90 \mathrm{~min}$ after breakf ast, $30 \mathrm{~min}$ before and $90 \mathrm{~min}$ after lunch and dinner, and at midnight) were carried out once or twice per week ( $4 \pm 0.4$ over 14-20 days) along with the measurement of circulating ketoamine-HbA. The M-value [14] was calculated as modified by Service et al. [15] week by week from all the blood glucose values of subjects. No symptoms of hypoglycaemia occurred during the fortnight before the test. On the day before the test, Lente insulin (Novo Industri) was omitted, and only soluble insulin was injected before each meal. Patients were connected to the Biostator $1-1^{1 / 2} \mathrm{~h}$ after dinner, between 18.30 and $19.00 \mathrm{~h}$ on the day before the test. At this time blood glucose was $6.56 \pm$ $0.32 \mathrm{mmol} / 1$ (range $5.447 .39 \mathrm{mmol} / 1$ ). Blood glucose values were maintained at preselected values $(4.44 \mathrm{mmol} / \mathrm{l})$ with the computer based device for insulin infusion. Minute-by-minute infusion rates were based on blood glucose determinations ( $4 / \mathrm{min}$ by glucose oxidase method) on continuously withdrawn venous blood $(50 \mathrm{ml} /$ $24 \mathrm{~h}$ ). The mean blood glucose level during the feedback programme was $5.17 \pm 0.02 \mathrm{mmol} / \mathrm{l}$ as calculated by a mean of blood glucose levels every $10 \mathrm{~min}$. Total insulin infused over $16 \mathrm{~h}$ of feedback was $19 \pm 2 \mathrm{U}$. Insulin infused over the $5 \mathrm{~h}$ before the test was $4.9 \pm 1.1 \mathrm{U}$. From 10.30 to $11.00 \mathrm{~h}$ of the test-day, the feedback programme was stopped and an insulin infusion at a constant rate for $60 \mathrm{~min}$ started. Blood glucose monitoring continued during the insulin infusion and for the next $60 \mathrm{~min}$. The rate of insulin infusion was the same as in normal subjects $\left(28 \mathrm{mU} / \mathrm{m}^{2}\right.$ per $\left.\mathrm{min}\right)$ though augmented by a supplementary dose $(16 \pm 4 \mathrm{mU} / \mathrm{min})$ as calculated from the mean basal infusion rate, which was necessary to keep blood glucose normal over the 5 -h period before the test. One litre $0.9 \%$ saline was infused over $2 \frac{1}{2} \mathrm{~h}$ from -30 to $120 \mathrm{~min}$ as in the control subjects.

\section{Analytical Methods}

In all subjects blood was drawn for measurement of glucagon, adrenaline, noradrenaline, growth hormone and cortisol. Plasma glucagon was determined by radioimmunoassay with $30 \mathrm{~K}$ antiserum [16]. This system can measure $20 \mathrm{pg} / \mathrm{ml}$ with greater than $99 \%$ confidence. Plasma growth hormone was also determined by radioimmunoassay [17]. Plasma catecholamines were determined by a sensitive and specific fluorimetric method, as previously reported [18]. Plasma cortisol was measured by Mattingly's fluorimetric method [19]. Plasma glucose was determined in diabetics, before the insulin infusion test, by Beckman glucose analyzer (Beckman Instruments, Fullerton, California). During the test blood glucose was measured by Biostator in all normal and diabetic subjects. In normal subjects, insulin was determined according to the method of Yalow and Berson [20], as modified by Herbert et al. [21]. The circulating ketoamine- $\mathrm{HbA}_{\mathrm{I}}$ was determined chromatographically after incubation of red cells in $0.9 \%$ saline at $37^{\circ} \mathrm{C}$ for $6 \mathrm{~h}$, as recently described [22]. Immuno-reactive C-peptide was determined before and $90 \mathrm{~min}$ after a mixed meal ( $297 \mathrm{Kcal}, 19 \%$ proteins, $38 \%$ lipids, $43 \%$ carbohydrate) according to the method of Beischer et al. [23]. The sensitivity of the assay method is $0.15 \mathrm{ng} / \mathrm{ml}$ with greater than $99 \%$ confidence. 
Table 2. Indices of glucose control of diabetic patients during the 14-20 day period of observation before the insulin infusion test

\begin{tabular}{|c|c|c|c|c|c|c|}
\hline & Days $1-7$ & & Days 8-14 & & Days $15-20$ & \\
\hline Fasting plasma glucose $(\mathrm{mmol} / \mathrm{l})$ & $5.67 \pm 0.17$ & $(7 \pm 0)$ & $5.50 \pm 0.17$ & $(7 \pm 0)$ & $5.61 \pm 0.22$ & $(3.7 \pm 0.9)$ \\
\hline $\begin{array}{l}\text { Post-meal }(90 \mathrm{~min}) \text { plasma glucose } \\
(\mathrm{mmol} / \mathrm{l})\end{array}$ & $7.94 \pm 0.06$ & $(11 \pm 0.6)$ & $7.44 \pm 0.11$ & $(7 \pm 0.6)$ & $7.44 \pm 0.06$ & $(3.8 \pm 0.8)$ \\
\hline $\begin{array}{l}\text { Mean daily plasma glucose from } \\
\text { glycaemic profile }(\mathrm{mmol} / \mathrm{l})\end{array}$ & $6.89 \pm 0.22$ & $(1.7 \pm 0.2)$ & $6.67 \pm 0.17$ & $(1 \pm 0.3)$ & $6.28 \pm 0.11$ & $(0.8 \pm 0.2)$ \\
\hline M-value & $10.4 \pm 0.7$ & $(23 \pm 1)$ & $5.9 \pm 0.7$ & $(17 \pm 1.3)$ & $5.7 \pm 0.3$ & $(10 \pm 2.1)$ \\
\hline Circulating ketoamine- $\mathrm{HbA}_{\mathrm{I}}[22](\%)$ & $8.84 \pm 0.10$ & $(1.7 \pm 0.2)$ & $8.30 \pm 0.10$ & $(1 \pm 0.3)$ & $8.25 \pm 0.10$ & $(0.8 \pm 0.2)$ \\
\hline
\end{tabular}

Results expressed as mean $\pm \mathrm{SEM}$; number of determinations/profiles shown in parentheses

\section{Statistical Methods}

We determined the area above or under the curve of blood glucose and counter-regulatory hormones by including the interval between zero time and the time at which basal value were again obtained. An index was calculated as the ratio between the area and the minutes considered. All results are expressed as mean \pm SEM. The results of the concentration of blood glucose and all counterregulatory hormones in normal subjects and in diabetic patients were compared at each time with the mean of the values at -15 and 0 min by the Wilcoxon signed rank sum test [24]. The Wilcoxon rank sum test for group comparison was used to analyse the difference of the indices (ratio of area to minutes) between diabetic and control subjects. Correlations between the index of blood glucose and that of all counter-regulatory hormones were calculated by the method of the least squares [24].

\section{Results}

\section{Normal Subjects}

Plasma insulin levels ranged from 44 to $51 \mathrm{mU} / 1$ (mean $49 \pm 1.3 \mathrm{mU} / 1$ ) during insulin infusion. Blood glucose decreased significantly at $15 \mathrm{~min}(4.67 \pm$ $0.16 \mathrm{mmol} / \mathrm{l})$ as compared with basal levels $(5.00 \pm$ $0.15 \mathrm{mmol} / 1, p \leqslant 0.05)$ and reached the nadir at $55 \mathrm{~min}(2.83 \pm 0.15 \mathrm{mmol} / 1)$. Blood glucose levels returned to the pre-infusion levels at $105 \mathrm{~min}$ (4.83 \pm $0.11 \mathrm{mmol} / \mathrm{l}, p=\mathrm{NS}$ compared with basal). The rate of decrease (from 0 to $55 \mathrm{~min}$ ) and increase in blood glucose (from 55 to $105 \mathrm{~min}$ ) were very close $(0.0389$ \pm 0.0028 versus $0.0400 \pm 0.0022 \mathrm{mmol} / \mathrm{min}, p=$ NS). A concomitant and significant increase in plasma glucagon (basal $82 \pm 7 \mathrm{pg} / \mathrm{ml}$, peak at $75 \mathrm{~min} 177$ $\pm 12 \mathrm{pg} / \mathrm{ml}$ ), adrenaline (basal $33 \pm 2 \mathrm{pg} / \mathrm{ml}$, peak at $65 \mathrm{~min} 299 \pm 65 \mathrm{pg} / \mathrm{ml}$ ), noradrenaline (basal $170 \pm$ $6 \mathrm{pg} / \mathrm{ml}$, peak at $55 \mathrm{~min} 539 \pm 77 \mathrm{pg} / \mathrm{ml}$ ) was evident at $30 \min (p \leqslant 0.05$ versus basal) and remained statistically significant up to $75 \mathrm{~min}$ for adrenaline, and $105 \mathrm{~min}$ for noradrenaline and glucagon. The increase in plasma growth hormone (basal $1.0 \pm 0.2 \mathrm{ng} / \mathrm{ml}$, peak at $75 \mathrm{~min} 30.6 \pm 7.2 \mathrm{ng} / \mathrm{ml}$ ) and in plasma cortisol (basal $8.0 \pm 1.2 \mu \mathrm{g} / \mathrm{dl}$, peak at $90 \mathrm{~min} 21 \pm 1.2 \mu \mathrm{g}$ / dl) were delayed compared with that of glucagon and catecholamines (Fig. 1). A significant correlation was found between the degree of blood glucose decrement and the increase in glucagon, catecholamines and cortisol, but not growth hormone (Table 3). On the other hand, no correlation was found between the blood glucose level at its nadir and the counter-regulatory hormone peaks.

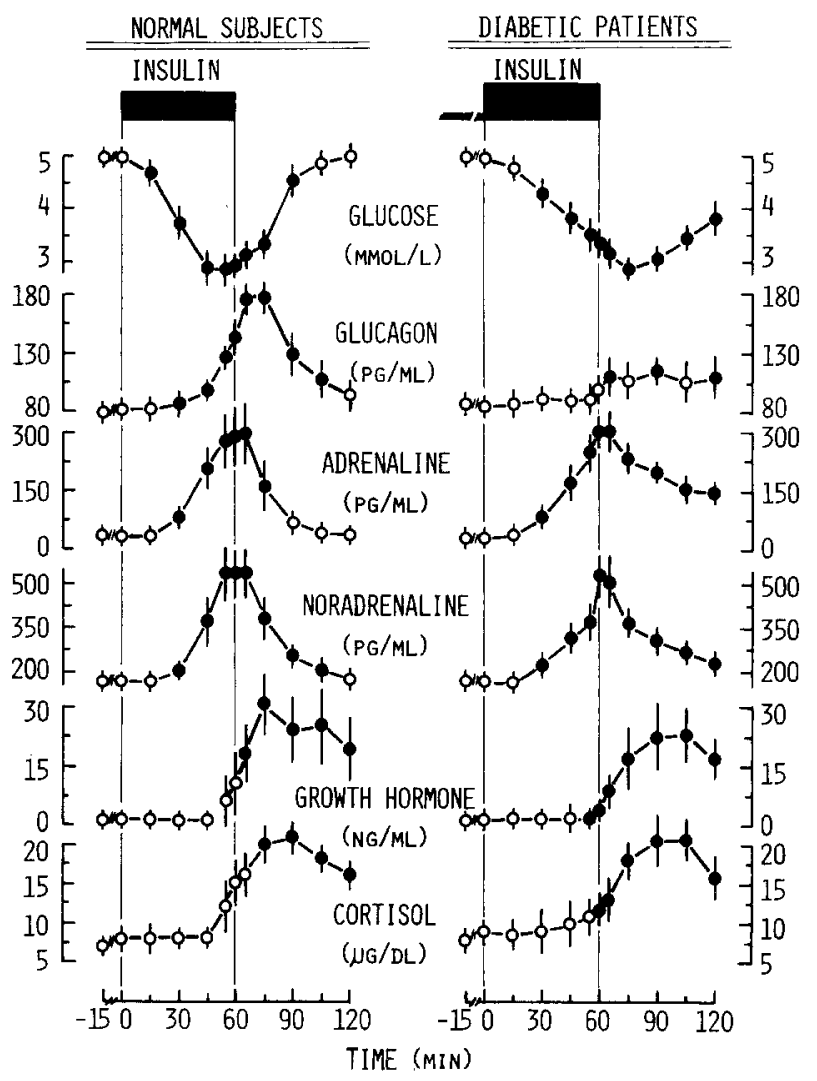

Fig. 1. Blood glucose and plasma counter-regulatory hormone levels before, during and after a constant IV insulin infusion for $60 \mathrm{~min}$.

Left panel: five normal subjects infused insulin at $28 \mathrm{mU} / \mathrm{m}^{2}$ per min.

Right panel: six Type 1 diabetic patients infused the same insulin dose as in normal subjects. The pre-test insulin infusion (basal infusion rate by Biostator needed to keep blood glucose normal over the five previous hours, $16 \pm 3.8 \mathrm{mU} / \mathrm{min}$ ) was continued during the test.

$(\bullet: p \leqslant 0.05$ versus basal; $0: p=$ NS versus basal) 
Table 3. Correlation coefficients between the index (calculated as area/min ratio) of blood glucose and of plasma counter-regulatory hormones in five normal subjects and in six diabetic patients during an IV insulin infusion for $60 \mathrm{~min}$

\begin{tabular}{|c|c|c|c|c|}
\hline & \multicolumn{2}{|c|}{ Normal subjects } & \multicolumn{2}{|c|}{ Diabetic subjects } \\
\hline & $r$ & $p$ & $r$ & $p$ \\
\hline Glucagon & 0.88 & $<0.025$ & 0.28 & NS \\
\hline Adrenaline & 0.84 & $<0.05$ & 0.77 & $<0.05$ \\
\hline Noradrenaline & 0.81 & $<0.05$ & 0.87 & $<0.01$ \\
\hline Growth hormone & 0.50 & NS & 0.68 & NS \\
\hline Cortisol & 0.89 & $<0.025$ & 0.96 & $<0.0025$ \\
\hline
\end{tabular}

NS: not significant

\section{Diabetic Patients}

Basal blood glucose levels $(4.94 \pm 0.09 \mathrm{mmol} / \mathrm{l})$ were not statistically different from those of normal subjects $(5.00 \pm 0.15 \mathrm{mmol} / \mathrm{l}, p=\mathrm{NS})$. Blood glucose decreased significantly at $30 \mathrm{~min}(4.28 \pm 0.21 \mathrm{mmol} / \mathrm{l}$, $p<0.05$ versus basal) and reached its nadir at $75 \mathrm{~min}$ $(2.89 \pm 0.11 \mathrm{mmol} / \mathrm{l})$, which was not statistically different from that of normal subjects $(2.83 \pm$ $0.15 \mathrm{mmol} / \mathrm{l})$. One hour after the end of insulin infusion (at $120 \mathrm{~min}$ ) blood glucose levels were still significantly lower than the pre-infusion values $(3.83 \pm$ $0.18 \mathrm{mmol} / \mathrm{l}, p<0.05)$. The rate of blood glucose decrease (from 0 to $75 \mathrm{~min}$ ) was significantly lower than in normal subjects $(0.0272 \pm 0.0022$ versus $0.0389 \pm$ $0.0028 \mathrm{mmol} / \mathrm{min}, p<0.05$ ). The rate of blood glucose recovery from the nadir to $120 \mathrm{~min}$ was about twofold slower than in normal subjects $(0.0206 \pm$ 0.0022 versus $0.0400 \pm 0.0022 \mathrm{mmol} / \mathrm{min}, p<0.05$ ). The index of blood glucose was $9 \%$ higher in diabetics than in normal subjects $(1.21 \pm 0.11$ versus $1.09 \pm$ $\left.0.12 \mathrm{mmol}^{-1} \mathrm{~min}^{-1}\right)$. Basal values of all counter-regulatory hormones did not differ statistically from those of controls. Catecholamine response was similar to that in controls and was significant at $30 \mathrm{~min}$ (adrenaline basal $31 \pm 2 \mathrm{pg} / \mathrm{ml}$, peak at $65 \min 299 \pm$ $38 \mathrm{pg} / \mathrm{ml}$; noradrenaline basal $166 \pm 5 \mathrm{pg} / \mathrm{ml}$, peak at $60 \mathrm{~min} 524 \pm 45 \mathrm{pg} / \mathrm{ml}$ ). Catecholamine increase closely correlated with blood glucose decrement as in controls (Table 3 ). The overall glucagon response in the diabetics was blunted and no peak clearly evident. In contrast to normal subjects, in whom the glucagon increase was simultaneous with that of catecholamines at $30 \mathrm{~min}$, glucagon levels in the diabetics at $30,45,55$, and $60 \mathrm{~min}$ were not significantly different from the basal levels. A statistically significant increase in glucagon was observed at $65 \mathrm{~min}(111 \pm 14$ versus basal $84 \pm 4 \mathrm{pg} / \mathrm{ml}, p<0.05$ ). However, in contrast to normal subjects, in whom the statistical significance of glucagon increase was persistent up to 105 min (time at which blood glucose returned to ba- sal values), in diabetics the increase in glucagon was no more significant at 75 and $105 \mathrm{~min}$, despite the nadir of blood glucose at $75 \mathrm{~min}$. In contrast to catecholamines, the index of glucagon was significantly lower in diabetics than in normal subjects $(23 \pm 2$ versus $40 \pm 4 \mathrm{pg} \mathrm{ml}^{-1} \mathrm{~min}^{-1}, p<0.05$ ) and did not correlate with blood glucose decrement (Table 3 ). The defective glucagon response correlated neither with the duration of diabetes, nor with residual pancreatic B cell function. However, in subjects who had had diabetes for 5 years or more (cases 1 and 2) there was virtually no response, while two cases with duration of diabetes for one month (cases 3 and 6) had a glucagon response peaking at $65 \mathrm{~min}$. The increase in plasma growth hormone (basal $1.3 \pm 0.2 \mathrm{ng} / \mathrm{ml}$, peak at $105 \mathrm{~min} 23.2 \pm 6.5 \mathrm{ng} / \mathrm{ml}$ ) and in plasma cortisol (basal $9 \pm 1 \mu \mathrm{g} / \mathrm{dl}$, peak at $105 \mathrm{~min} 21 \pm 2 \mu \mathrm{g} / \mathrm{dl}$ ) were delayed compared with that of catecholamines, as observed in normal subjects (Fig. 1). The indices of cortisol and growth hormone in diabetics were similar to those in normal subjects. Cortisol index, but not growth hormone, significantly correlated with blood glucose decrement, as in normal subjects (Table 3 ).

\section{Discussion}

At present, a growing number of subjects are treated with intensive conventional insulin regimens and artificial devices on a long-term basis. In these subjects blood glucose is often kept very close to the normal range, but the risk of hypoglycaemia may be higher than with less intensive therapeutic regimens. Therefore we have investigated the mechanisms of glucose counter-regulation in diabetics with prolonged normalisation of blood glucose levels.

The overall dose of insulin infused in our normoglycaemic diabetics during the test provoked a slow and moderate decrement in blood glucose which was never below $2.89 \mathrm{mmol} / 1$. This type of study allowed a detailed analysis of the rate of blood glucose decrement and recovery as well as of the counter-regulatory response of different hormones.

Although the insulin infusion was carried out with exactly the same protocol in the normal subjects as in the diabetic patients, the pattern of the blood glucose curve during and after the test was different in the two groups, except for the absolute value of the minimal blood glucose level reached. In the diabetics the blood glucose decrement was slower, the nadir markedly delayed and the blood glucose recovery impaired compared with normal subjects. While the first two of these differences may be explained by the delayed onset of the injected insulin action in diabetics $[25,26]$ possibly due to circulating anti-insulin antibodies, the third might depend on the different hor- 
monal counter-regulatory response to blood glucose decrement observed in diabetics.

In diabetics, the patterns of counter-regulatory hormone response to insulin-induced blood glucose fall were exactly the same as in normal subjects with the exception of glucagon, the response of which was blunted despite the prolonged period of blood glucose optimization.

The significant increase in both noradrenaline and adrenaline observed in the diabetics is fully in line with the report of Santiago et al. [12]. On the other hand, Saccà et al. [9] did not observe any significant increase in noradrenaline during a fall of blood glucose from $12.33 \pm 0.39$ to $3.28 \pm 0.28 \mathrm{mmol} / 1$ (rate $0.06 \mathrm{mmol} / \mathrm{min}$ ), while the increase in adrenaline was significant. The adrenaline and noradrenaline response in our diabetic patients was very similar to that of the normal subjects and closely correlated with blood glucose decrement, suggesting that both catecholamines equally and significantly respond to hypoglycaemia in diabetics. The response of cortisol and growth hormone was delayed compared with that of catecholamines and was similar in diabetics and normal subjects, as reported in the majority of previous studies $[5,8,12,27,28]$.

Glucagon response to insulin-induced blood glucose fall was significantly impaired in all our diabetics. This defective A cell response, first observed by Gerich et al. [5], has been reported in all the studies investigating diabetics with long-term high blood glucose levels $[8,9,11]$. A similar blunted glucagon response to hypoglycaemia has been reported by Ensinck and Kanter [29] in four Type 1 diabetics $24 \mathrm{~h}$ after glucoregulation by Biostator, and by Ohneda et al. [30] in seven diabetics investigated after conventional treatment. In our diabetics, despite the prolonged period of previous blood glucose optimization, the A cell response to the insulin-induced blood glucose decrement did not approach the normal range, but remained clearly blunted. This suggests that the defective glucagon release to hypoglycaemia in diabetics is not merely the consequence of insulin deficiency. It is well known, on the other hand, that the diabetic A cell is characterized by another abnormality, i.e. the sustained glucagon secretion which is inappropriate to the ambient glucose concentration and to IV arginine [31]. This defect may be reversed in part or in total by short- or long-term appropriate insulin treatment [32-34]. Therefore, in contrast to the above-mentioned impaired glucagon response to hypoglycaemia, it is generally accepted that hyperglucagonaemia, as well as other hormone [35] and metabolite [36] abnormalities in diabetes mellitus, is a secondary event closely related to insulin deficiency.

Although there was no correlation either with diabetes duration or with residual pancreatic $B$ cell func- tion, the A cell abnormality was more pronounced in diabetics of long standing, suggesting that it may appear soon after the onset of diabetes and progress during the course of the illness. At present, the cause of the impaired glucagon response to hypoglycaemia in diabetics is unknown. Initially, Gerich et al. [5] suggested a selective impairment of the A cell glucoreceptor in Type I diabetes. The later hypothesis of autonomic neuropathy $[7,8]$ affecting the control of glucagon release in diabetics seems no longer tenable after the definitive demonstration that glucagon response to hypoglycaemia is independent of vagal [37] and adrenergic control [38-40]. Very recently, however, Madsbad et al. [41] have found that the residual glucagon response to hypoglycaemia is greater in Type I diabetics with pancreatic B cell reserve and without autonomic neuropathy compared with other subjects without B cell reserve with or without neuropathy. These data would suggest that a physiological relationship exists between A, B and D cells for a prompt and efficient glucagon response to hypoglycaemia. Moreover, a super-sensitivity of the A cells to the suppressive effects of the insulin administered has been suggested in diabetes (R.H. Unger, personal communication).

In conclusion, the blunted glucagon response in normoglycaemic diabetics, in whom the other counter-regulatory hormones respond normally, could well be the cause of their impaired recovery from hypoglycaemia. However, the possible role of the concomitant prolonged activity of injected insulin cannot be excluded.

Acknowledgements. The authors gratefully acknowledge Dr. John E. Gerich for reviewing the manuscript and for his help in discussing the results obtained. We wish to thank Mrs. N. Pannaccio, Mr. F.Alunni, Mr. F.Cimarelli, Mr. G.Cipiciani, Mr. M. Frattegiani, Mr. R.Pippi for their excellent technical assistence. This work was supported by the Italian National Research Council (C.N.R., grant No.80.00393.04/115).

Presented in part at the 41st Meeting of the American Diabetes Association (Cincinnati, 14-16 June 1981) and at the 17th Meeting of the European Association for the Study of Diabetes (Amsterdam, 15-18 September 1981).

\section{References}

1. Rizza RA, Cryer PE, Gerich JE (1979) Role of glucagon, catecholamines, and growth hormone in human glucose counterregulation. J Clin Invest 64: 62-71

2. Garber AJ, Cryer PE, Santiago JV, Haymond MW, Pagliara AS, Kipnis DM (1976) The role of adrenergic mechanisms in the substrate and hormonal response to insulin-induced hypoglycaemia in man. J Clin Invest 58:7-15

3. Gerich J, Cryer P, Rizza R (1980) Hormonal mechanisms in acute glucose counterregulation: the relative roles of glucagon, epinephrine, norepinephrine, growth hormone and cortisol. Metabolism 29: 1164-1175

4. Brodows RG, Pi-Sunyer FX, Campbell RG (1973) Neural control of counter-regulatory events during glucopenia in man. $J$ Clin Invest 52: 1841-1844 
5. Gerich JE, Langlois M, Noacco C, Karam JH, Forsham PH (1973) Lack of glucagon response to hypoglycemia in diabetes: evidence for an intrinsic pancreatic alpha cell defect. Science 182: 171-173

6. Benson JW Jr, Johnson DG, Palmer JP, Werner PL, Ensinck JW (1977) Glucagon and catecholamine secretion during hypoglycaemia in normal and diabetic man. J Clin Endocrinol Metab 44: $459-464$

7. Maher TD, Taneberg RJ, Greenberg BZ, Hoffman JE, Doe RP, Goetz FC (1977) Lack of glucagon response to hypoglycaemia in diabetic autonomic neuropathy. Diabetes 26: 196-200

8. Campbell LV, Kraegen EW, Lazarus L (1977) Defective blood glucose counterregulation in diabetics in a selective form of autonomic neuropathy. Br Med J 2: 1527-1529

9. Saccà L, Sherwin R, Hendler R, Felig P(1979) Influence of continuous physiologic hyperinsulinemia on glucose kinetics and counterregulatory hormones in normal and diabetic humans. $J$ Clin Invest 63: 849-857

10. Campbell LV, Kraegen EW, Meler H, Lazarus L (1979) Hormonal responses to insulin infusion in diabetes mellitus. Diabetologia 16:359-364

11. Viberti GC, Keen H, Bloom SR (1980) Beta blockade and diabetes mellitus: effect of oxprenolol and metoprolol on the metabolic, cardiovascular, and hormonal response to insulin-induced hypoglycemia in insulin-dependent diabetics. Metabolism 29:873-879

12. Santiago JV, Clarke WL, Shah SD, Cryer PE (1980) Epinephrine, norepinephrine, glucagon and growth hormone release in association with physiological decrements in the plasma glucose concentration in normal and diabetic man. J Clin Endocrinol Metab 51: 877-883

13. Mackay JD, Page M McB, Cambridge J, Watkins PJ (1980) Diabetic autonomic neuropathy. Diabetologia 18:471-478

14. Schlichtkrull J, Munck O, Jersild M (1965) The M-value, an index of blood sugar control in diabetics. Acta Med Scand 177: 95-102

15. Service FJ, Molnar GD, Rosevear JW, Ackerman E, Gatewood LC, Taylor WF (1970) Mean amplitude of glycemic excursions, a measure of diabetic instability. Diabetes 19:644-655

16. Faloona G, Unger R (1974) Glucagon. In: Jaffe B, Behrman H (eds) Methods of hormone radioimmunoassay. Academic Press, New York, pp 317-330

17. Peake G (1974) Growth hormone. In: Jaffe B, Behrman H(eds) Methods of hormone radioimmunoassay. Academic Press, New York, pp 103-121

18. Bolli G, Cartechini MG, Compagnucci P, Malvicini S, De Feo P, Angeletti G, Santeusanio F, Brunetti P(1979) Effect of metabolic control on urinary excretion and plasma levels of catecholamines in diabetics. Horm Metab Res 11:493-497

19. Mattingly D (1964) A simple fluorimetric method for the estimation of 11-hydroxy-corticoids in human plasma. J Clin $\mathrm{Pa}$ thol 15:374-379

20. Yalow RS, Berson SA (1960) Immunoassay of endogenous plasma insulin in man. J Clin Invest 39: 1157-1175

21. Herbert V, Lav KS, Gottlieb GW, Bleicher SJ (1965) Coated charcoal immunoassay of insulin. J Clin Endocrinol Metab 25: 1375-1384

22. Compagnucci P, Cartechini MG, Bolli G, De Feo P, Santeusanio $F$, Brunetti $P(1981)$ The importance of determining irreversibly glycosylated hemoglobin in diabetics. Diabetes 30 : 607-612.

23. Beischer W, Keller L, Maas M, Schiefer E, Pfeiffer EF (1976) Human C Peptide, part I: radioimmunoassay. Klin Wochenschr 54: 709-716

24. Armitage P (1971) Statistical methods in medical research. Blackwell, Oxford, Edinburgh, pp 147-166, 394-407

25. Berson SA, Yalow RS, Bauman A, Rothchild MA, Newerly K
(1956) Insulin- ${ }^{131}$ I metabolism in human subjects. J Clin Invest 35: 170-190

26. Gibson RC, Stretcher GS, Williams TF (1966) Duration and magnitude of insulin effect in juvenile-onset diabetics. Clin Res $14: 63$

27. Santeusanio F, Bolli G, Massi-Benedetti M, De Feo P, Angeletti G, Compagnucci P, Calabrese G, Brunetti P(1981) Counter-regulatory hormones during moderate, insulin-induced, blood glucose decrements in man. J Clin Endocrinol Metab 52: $477-482$

28. De Feo P, Santeusanio F, Bolli G, Calabrese G, Compagnucci P, Cartechini MG, Angeletti G (1981) Counter-regulatory hormone response during prolonged but moderate hyperinsulinemia in normal man. Pan Med 23 : in press

29. Ensinck JW, Kanter RA (1980) Glucagon responses to hypoglycemia in type 1 diabetic man after 24-hour glucoregulation by glucose-controlled insulin infusion. Diabetes Care 3: 285-289

30. Ohneda A, Watanabe K, Horigome K, Sakai T, Kai Y, Oikawa S (1978) Abnormal response of pancreatic glucagon to glycemic changes in diabetes mellitus. J Clin Endocrinol Metab 46: $504-510$

31. Unger RH (1971) Glucagon physiology and pathophysiology. N Engl J Med 285: 443-449

32. Shichiri M, Kawamori R, Abe H (1979) Normalization of the paradoxic secretion of glucagon in diabetics who were controlled by the artificial beta cell. Diabetes $28: 272-275$

33. Raskin P, Pietri A, Unger R (1979) Changes in glucagon levels after four to five weeks of glucoregulation by portable insulin infusion pumps. Diabetes 28: 1033-1035

34. Kawamori R, Shichiri M, Kituchi M, Yamasaki Y, Abe H (1980) Perfect normalization of excessive glucagon responses to intravenous arginine in human diabetes mellitus with the artificial beta-cell. Diabetes 29:762-765

35. Tamborlane WV, Sherwin RS, Koivisto V, Hendler R, Gessel M, Felig P (1979) Normalization of the growth hormone and catecholamine response to exercise in juvenile-onset diabetic subjects treated with a portable insulin-infusion pump. Diabetes 28: 785-788

36. Pickup JC, Keen H, Person JA, Alberti KGMM, Rwo AS (1979) Continuous subcutaneous insulin infusion: improved blood glucose and intermediary metabolites in diabetics. Lancet 1 : $1255-1258$

37. Palmer JP, Werner PL, Hollander P, Ensinck JW (1979) Evaluation of the control of glucagon secretion by the parasympathetic nervous system in man. Metabolism 28: 549-552

38. Walter RM, Dudl RJ, Palmer JP, Ensinck JW (1974) The effect of adrenergic blockade on the glucagon response to starvation and hypoglycemia in man. J Clin Invest 54: 1214-1220

39. Ensinck JW, Walter RM, Palmer JP, Brodows RG, Campbell RJ (1976) Glucagon responses to hypoglycaemia in adrenalectomized man. Metabolism 25:227-232

40. Palmer JP, Henry DP, Benson JW, Johnson DG, Ensinck JW (1976) Glucagon response to hypoglycaemia in sympathectomized man. J Clin Invest 57: 522-525

41. Madsbad S, Hilsted J, Krarup T, Tronier B, Schwartz T (1981) The importance of autonomic neuropathy and of residual $\beta$-cell function for the pancreatic endocrine response to hypoglycemia in insulin-dependent diabetics. Diabetes 30 (Suppl 1): 44A

Received: 16 March 1981

and in revised form: 5 October 1981

Geremia Bolli, M.D.

Istituto Patologia Medica Università

Via del Giochetto

I-06100 Perugia, Italy 